\title{
PROSES PEMBELAJARAN PROGRAM HOMESCHOOLING TINGKAT SEKOLAH DASAR DI PKBM ANUGRAH BANGSA KOTA SEMARANG
}

\author{
DAMEIS SURYA ANGGARA ${ }^{1)}$, CANDRA ABDILLAH ${ }^{2)}$ \\ ${ }^{1,2}$ Dosen Program Studi Pendidikan Ekonomi Universitas Pamulang \\ dameis_surya@yahoo.com ${ }^{1)}$,candra_abdillah@yahoo.com ${ }^{2)}$
}

\begin{abstract}
ABSTRAK
Penelitian ini bertujuan untuk mengetahui: (1) perencanaan pembelajaran, (2) pelaksanaan pembelajaran, (3) penilaian pembelajaran dan (4) pengawasan pembelajaran program homeschooling tingkat Sekolah Dasar di PKBM Anugrah Bangsa Kota Semarang. Penelitian ini menggunakan pendekatan kualitatif dengan metodologi Phenomenology. Subjek penelitian adalah koordinator Sekolah Dasar, tutor, dan homeschooler kelas 4 dan 6. Pengumpulan data dilakukan melalui wawancara, observasi, dan dokumentasi. Keabsahan data dilakukan melalui triangulasi sumber dan triangulasi teknik. Analisis data diperoleh melalui pengumpulan data, penyajian data, reduksi, dan kesimpulan. Hasil penelitian mengungkapkan bahwa: (1) perencanaan pembelajaran disusun setiap awal semester, yang meliputi pembuatan program tahunan, program semester, silabus, dan rencana pelaksanaan pembelajaran, (2) pelaksanaan pembelajaran terbagi menjadi dua sistem pembelajaran, yaitu sistem komunitas, dan sistem Distance Learning dengan menerapkan berbagai model pembelajaran seperti model Numbered heads Together, Snowball Throwing, Talking Stick, Think Pair Share, dll yang dikombinasikan dengan E-Learning, (3) penilain pembelajaran yang dilaksanakan antaralain tugas individual, tugas kelompok, tugas proyek, tugas produk, ujian tengah semester, ujian akhir semester, ujian praktik, ujian sekolah bertaraf nasional yang wajib diikuti oleh semua siswa, (4) pengawasan pembelajaran dilakukan secara berkala oleh Koordinator Sekolah Dasar dan Pengawas Internal Sekolah, seperti pengecekan daftar hadir tutor, daftar hadir siswa, perencanaan pembelajaran, proses pembelajaran, dan proses penilaian pembelajaran.
\end{abstract}

Kata Kunci : homeschooling, pembelajaran, sekolah dasar.

PENDAHULUAN

Pendidikan merupakan pilar terpenting dalam pembangunan untuk memajukan bangsa dan negara. Berdasarkan Undang-undang No. 20
Tahun 2003 tentang Sistem Pendidikan Nasional Pasal 13 ayat (1) dijelaskan bahwa "Jalur pendidikan terdiri atas pendidikan formal, nonformal, dan informal". Pemerintah 
menjamin kebebasan kepada warga negara untuk memilih jalur pendidikan yang sesuai dengan kebutuhan dan kemampuan masyarakat.

Pendidikan di Indonesia diatur berdasarkan 8 standar nasional pendidikan. Salah satu standar pendidikan tersebut adalah standar proses. Menurut Peraturan Menteri Pendidikan dan Kebudayaan No. 3 Tahun 2008 dijelaskan bahwa standar proses berisi kriteria minimal proses pembelajaran pada satuan pendidikan dasar dan menengah di seluruh wilayah hukum Negara Kesatuan Republik Indonesia. Standar proses ini berlaku untuk jenjang pendidikan dasar dan menengah pada jalur formal, balk pada sistem paket maupun pada sistem kredit semester. Standar proses meliputi perencanaan proses pembelajaran, pelaksanaan proses pembelajaran, dan pengawasan proses pembelajaran untuk terlaksananya proses pembelajaran yang efektif dan efisien.

Proses pendidikan harus mengedepankan peran aktif peserta didik dengan diberi hak dan kesempatan untuk ikut menentukan apa yang terbaik untuk dirinya. Ini mengandung makna bahwa pendidikan mestinya memperhatikan minat dan kebutuhan siswa dalam memilih dan menentukan kurikulum yang akan dijalaninya sebagai bekal hidup yang diperlukan untuk mengukir masa depan dirinya, masyarakat, bangsa dan negaranya.

Pembelajaran pada pendidikan formal yang ada di Indonesia dilaksanakan dalam bentuk lembaga sekolah diharapkan menjadi ajang belajar yang menggairahkan untuk meningkatkan rasa ingin tahu anak. Namun pada kenyataannya, suasana sekolah formal saat ini banyak didominasi oleh pemikiran yang keliru, sehingga justru mengubah anak-anak yang pada dasarnya sangat kreatif menjadi robot-robot kaku yang sangat penurut (Mulyadi, 2007:136). Sehingga proses pendidikan yang terjadi di sekolah formal belum mampu memberikan suasana yang aman, nyaman, menyenangkan, dan menggairahkan peserta didika untuk mengembangkan bakat, minat dan potensi pribadinya secara optimal.

Berdasarkan realita di atas, sebagian orang tua yang peduli terhadap perkembangan bakat dan minat anak-anaknya mencari solusi untuk menjawab permasalahan pendidikan tersebut. Hal inilah yang kemudian menjadi faktor berkembangnya homeschooling. Ananda (2017), homeschooling berkembang di Indonesia terjadi akibat dari rasa ketidakpercayaan terhadap sekolah formal karena kurikulum terus berubah (ganti menteri ganti kurikulum) dan dirasakan memberatkan peserta didik, terdapat pula anggapan anak sebagai objek bukan subjek, memasung kreatifitas dan kecerdasan anak, baik segi emosional, moral, maupun spiritual.

Kembara

menjelaskan bahwa homeschooling menjadi konsep alternatif yang layak diterapkan untuk memberi pilihan 
setiap orang dalam menguasai pengetahuan sesuai dengan gaya mereka masing-masing.

Homeschooling dianggap sebagai salah satu inovasi pendidikan untuk alternatif mengembangkan potensi anak. Hal ini sesuai dengan hasil penelitian dari Fitriana (2016) menyatakan bahwa pendidikan homeschooling efektif untuk mengembangkan potensi anak di homeschooling Kak Seto Jakarta Selatan. Homeschooling berdasarkan Dinas Pendidikan Luar Sekolah Departemen Pendidikan Nasional (2002), adalah proses layanan pendidikan yang secara sadar, teratur dan terarah dilakukan orangtua/ keluarga di rumah atau tempat-tempat lain. Di Indonesia, terdapat sekitar 10.001.500 siswa homeschooling (Sumardiono, 2007).

$$
\text { Pelaksanaan pembelajaran }
$$

pada pendidikan homeschooling sudah diteliti beberapa penelitian sebelumnya. Menurut Ariefianto (2017) mengkaji homeschooling dari segi persepsi, latar belakang, dan problematika di homeschooling Kabupaten Jember. Sedangkan penelitian dari Vibriyanthy (2014) mengkaji tentang implementasi pendidikan karakter di homeschooling Kak Seto Yogyakarta. Dari beberapa penelitian tersebut, peneliti mengkaji pelaksanaan pembelajaran homeschooling di PKBM Anugrah Bangsa Semarang.

Berdasarkan uraian di atas, rumusan masalah yang dikaji dalam penelitian ini adalah (1) bagaimana perencanaan pembelajaran program homeschooling tingkat sekolah dasar di PKBM Anugrah Bangsa Semarang; (2) bagaimana pelaksanaan pembelajaran program homeschooling tingkat sekolah dasar di PKBM Anugrah Bangsa Semarang; (3) bagaimana pengawasan pembelajaran program homeschooling tingkat sekolah dasar di PKBM Anugrah Bangsa Semarang; (4) bagaimana penilaian pembelajaran program homeschooling tingkat sekolah dasar di PKBM Anugrah Bangsa Semarang.

\section{METODE PENELITIAN}

Penelitian ini menggunakan pendekatan kualitatif dengan metodologi phenomenology. Menurut Sugiyono (2012) bahwa penelitian kualitatif merupakan metode penelitian yang digunakan untuk meneliti pada kondisi obyek yang alamiah, dimana peneliti adalah sebagai instrument kunci, teknik pengumpulan data menggunakan wawancara mendalam, observasi dan dokumentasi, untuk validasi data dilakukan secara triangulasi (gabungan), analisis data bersifat induktif, dan hasil penelitian kualitatif lebih menekankan makna dari pada generalisasi.

Metodologi penelitian ini adalah phenomenology yaitu mendeskripsikan fenomena di suatu komunitas tertentu. Penelitian ini mendiskripsikan perencanaan pembelajaran, pelaksanaan pembelajaran, pengawasan pembelajaran, dan penilaian pembelajaran pada program homeschooling tingkat sekolah dasar di PKBM Anugrah 
Bangsa Semarang. Kehadiran peneliti di lokasi penelitian adalah sebagai instrumen dalam penelitian. Peneliti merupakan salah satu anggota manajemen yang menjabat sebagai koordinator sekolah dasar periode 2014-2016. Kehadiran peneliti dimulai sejak 2013, sehingga peneliti secara insentif menggali data pada akhir 2016.

Lokasi penelitian ini adalah PKBM Anugrah Bangsa Semarang, Indonesia. Awal berdirinya homeschooling ini menggunakan nama HSKS (homeschooling Kak Seto). Akan tetapi pada tahun 2014 homeschooling tersebut sudah mengganti nama menjadi homeschooling PKBM Anugrah Bangsa.

Subjek penelitian adalah 1 orang koordinator sekolah dasar, 3 orang tutor sekolah dasar, dan 2 siswa (homeschooler) sekolah dasar. Subjek didapat dengan menggunakan teknik purposive yaitu karakteristik telah ditentukan dan diketahui lebih dulu berdasarkan ciri maupun sifat populasinya, sehingga sampel yang diteliti sudah khusus maka tidak perlu menciptakan suatu kondisi tertentu ataupun subjek yang diambil secara acak ataupun insidental.

Pengumpulan

data

menggunakan teknik wawancara mendalam, observasi, dan dokumentasi. Analisis data dilakukan melalui pengumpulan data, reduksi data, penyajian data dan penarikan kesimpulan. Keabsahan data menggunakan teknik triangulasi sumber yaitu koordinator sekolah dasar, tutor, dan siswa/homeschooler. Adapun triangulasi teknik berupa wawancara, dokumentasi, dan observasi.

\section{HASIL DAN PEMBAHASAN}

Program homeschooling di PKBM Anugrah Bangsa merupakan salah satu satuan pendidikan nonformal yang dilaksanakan secara terstruktur dan berjenjang. PKBM Anugrah Bangsa memiliki program utama dan program pendukung PKBM. Program utama dari PKBM Anugrah bangsa adalah pendidikan kesetaraan dengan teknik pembelajaran homeschooling dan program pendukungnya meliputi taman baca masyarakat, kursus pertanian terintegrasi, kursus bahasa inggris dan seni musik. Program homeschooling di PKBM Anugrah Bangsa terdiri dari 3 jenjang, yaitu Paket A setara SD, Paket B setara SMP, dan Paket C setara SMA.

Pembelajaran

di homeschooling setiap jenjang tersebut dibagi menjadi 2 jenis kegiatan pembelajaran, yaitu pembelajaran komunitas dan pembelajaran DL (distance learning). Pembelajaran komunitas dilaksanakan di sekolah sesuai tingakatan kelas dengan jadwal senin dan rabu pukul 09.00 hingga 12.10 WIB, serta jumat pukul 09.00 11.00. Satu hari pembelajaran terdiri dari 5 jam pelajaran dengan alokasi waktu 35 menit per jam pelajaran. Sedangkan pembelajaran distance learning atau sering disebut pembelajaran visit dilaksanakan berdasarkan kesepakatan hari belajar 
anatara koordinator dan orang tua. Biasanya pembelajaran visit dilakukan hari selasa dan kamis mulai pukul 09.00 hingga 12.00 WIB.

Mata pelajaran yang diajarkan di sekolah dasar ada 8 mata pelajaran, yaitu Matematika, Ilmu Pengetahuan Alam, Ilmu Pengetahuan Sosial, Bahasa Indonesia, Pendidikan Agama, Pendidikan Kewarganegaraan, Seni Budaya Dan Keterampilan, Penjasorkes, Muatan Lokal yang terdiri dari Bahasa Jawa dan Bahasa Inggris, serta ketrampilan fungsional berupa Pertanian Terintegrasi.

\section{Perencanaan Pembelajaran}

Hasil wawancara subyek pertama (koordinator sekolah dasar) menyatakan bahwa sebelum adanya pembelajaran, semua tutor sekolah dasar diwajibkan untuk membuat perangkat perencanaan pembelajaran. Hal ini dikarenakan agar pelaksanaan pembelajaran dapat terlaksana sesuai dengan tujuan pembelajaran. Perangkat pembelajaran tersebut antara lain: program tahunan, program semester, silabus, rencana pelakasanaan pembelajaran (RPP). Perangkat pembelajaran tersebut disusun oleh tutor masing-masing pengampu mata pelajaran sekolah dasar setiap awal semester. Semua tutor baik tutor komunitas yang mengajar di sekolah maupun tutor visit yang datang ke rumah diwajibkan membuat perangkat pembelajaran tersebut disesuaikan dengan kalender pendidikan sekolah. Perangkat pembelajaran dikumpulkan dalam bentuk softcopy dan hardcopy kepada koordinator sekolah dasar dan pengawas internal sekolah.

Hasil wawancara subjek kedua (tutor sekolah dasar) menyatakan bahwa pembuatan perangkat pembelajaran selalu dibuat di awal semester sebagai acuan pelaksanaan pembelajaran satu semester ke depan. Perangkat pembelajaran yang dibuat berupa program tahunan, program semester, silabus, dan RPP disesuaikan dengan kalender pendidikan sekolah. Homeschooling PKBM Anugrah Bangsa menerapkan kurikulum 2013 dengan jumlah pertemuan minimal 18 minggu per semester. Pembuatan perangkat pembelajaran antara tutor komunitas dan tutor visit mengalami beberapa perbedaan, dikarenakan metode pembelajarannya berbeda. Tutor mendapatkan banyak manfaat dengan pembuatan perangkat pembelajaran, karena tutor dapat menyesuaikan waktu belajar dengan materi pelajaran.

\section{Pelaksanaan Pembelajaran}

Pelaksanaan pembelajaran program homeschooling tingkat sekolah dasar di PKBM Anugrah Bangsa dilakukan melalui dua sistem pembelajaran, yaitu 1) sistem komunitas, dan 2) sistem Distance Learning. Proses pembelajaran kedua sistem tersebut menerapkan berbagai model pembelajaran seperti model Numbered heads Together, Snowball Throwing, Talking Stick, Think Pair Share, dll yang dikombinasikan dengan E-Learning.

Hasil wawancara dan observasi, subjek pertama 
(koordinator sekolah dasar) menyatakan bahwa pelaksanaan pembelajaran di homeschooling hampir sama dengan pelaksanaan pembelajaran di sekolah formal, akan tetapi menyesuaikan dengan aturan kesetaraan. Hal ini sesuai dengan penjelasan Mulyadi (2007:52) sebagai bentuk dari pendidikan informal kunci utama penyelenggaraan homeschooling adalah adanya kelenturan atau fleksibilitas. Pelaksanaan pembelajaran tidak boleh kaku dan terlalu berstruktur seperti sekolah formal. Jika terlalu disusun dalam kurikulum yang baku maka homeschooling akan kehilangan makna utamanya namun bukan berarti tanpa arahan yang jelas. Fleksibilitas homeschooling tetap dilaksanakan dengan penuh tanggung jawab khususnya orang tua memiliki peranan besar dalam pendidikan anaknya.

Berdasarkan observasi pola pengelolaan kelas yang digunakan para tutor komunitas sekolah dasar meliputi tatap muka/klasikal, kelompok kecil, tutorial, dan kegiatan mandiri. Sedangkan para tutor visit memiliki pola pembelajaran tutorial dan kegiatan mandiri. Hal ini dikarenakan untuk komunitas terdiri dari lebih dari 5 anak di kelas, sedangkan untuk visit tutor hanya mengajar 1 siswa di rumah.

Tutor-tutor komunitas menerapkan berbagai metode dan model pembelajaran. Metode pembelajaran yang diterapkan antara lain ceramah, tanya jawab, diskusi, tugas kelompok, tugas individual, dan praktik. Selain itu juga sering menerapkan model pembelajaran seperti model Numbered heads Together, Snowball Throwing, Talking Stick, Think Pair Share, dll. Variasi metode dan model pembelajaran yang diterapkan dalam proses pembelajaran bertujuan agar siswa semakin aktif, rasa ingin tahu meningkat, dan motivasi belajar dapat meningkat, sehingga hasil belajarpun semakin baik. Tutor juga sering menggunakan media pembelajaran untuk mendukung ketercapaiaan tujuan pembelajaran. Contoh media pembelajaran yang digunakan adalah Peta, Atlas, Globe, Video Pembelajaran, dll. Hal ini sesuai dengan penelitian dari Anggara (2013) menyatakan bahwa penerapan model think pair share dan media CD pembelajaran dapat meningkatkan kualitas pembelajaran siswa sekolah dasar meliputi meningkatnya hasil belajar siswa, aktivitas siswa, dan ketrampilan guru dalam mengajar.

Selain pembelajaran dengan sistem komunitas dan distance learning, siswa homeschooling juga diwajibkan untuk mengikuti $e$ leraning. Tutor setiap mata pelajaran mengunggah materi ajar dan latihan soal ke web yang sudah disediakan oleh pihak homeschooling. Kemudian siswa belajar mandiri dan mengerjakan soal tersebut secara online sesuai dengan waktu yang telah ditentukan.

Hasil wawancara terhadap beberapa siswa/homeschooler menjelaskan bahwa pelaksanaan pembelajaran yang dilakukan oleh 
tutor menerapkan berbagai variasi pembelajaran. Pembelajaran di sekolah menjadi menyenangkan karena siswa tidak hanya mendengarkan ceramah dari tutor, akan tetapi siswa secara aktif ikut serta dalam pembelajaran. Contoh pembelajaran IPA yang diberikan salah satu tutor adalah praktik tentang energi dan perubahannya di laboratorium. Siswa mengikuti dengan sangat antusias melakukan praktikum sesuai dengan instruksi tutor. Hal ini sesuai dengan penelitian Abdillah (2017) menyebutkan bahwa pembelajaran yang dilakukan dengan menerapkan pengamatan langsung dapat meningkatkan keterampilan proses sains dan pemahaman konsep siswa.

\section{Penilaian Pembelajaran}

Homeschooling

PKBM

Anugrah Bangsa menerapkan beberapa jenis penilaian setelah terlaksananya pembelajaran. Jenis penilain dilaksanakan melalui tugas individual, tugas kelompok, tugas proyek, tugas produk, ujian tengah semester, ujian akhir semester, ujian praktik, ujian sekolah bertaraf nasional. Semua siswa dictance learning dan siswa komunitas wajib mengikuti semua jenis penilaian tersebut. Hasil penilaian didokumentasikan oleh setiap tutor dalam bentuk photocopy jawaban siswa, kemudian dikumpulkan kepada koordinator sekolah dasar. Selain penilaian kepada siswa.

Berdasarkan wawancara terhadap tutor diperoleh informasi bahwa sistem penilaian menggunakan berbagai metode seperti penugasan, ulangan harian, ulangan tengah semester, ulangan akhir semester, ujian sekolah bertaraf nasional. Selain itu berdasarkan observasi serta wawancara terhadap siswa, diperoleh informasi bahwa siswa pernah mendapatkan tugas proyek seperti "menanam dan memanen tanaman di hidroponik". Selain itu siswa pernah mendapatkan tugas membuat produk "memanfaatkan barang bekas menjadi hal yang memiliki daya guna".

\section{Pengawasan Pembelajaran}

Pengawasan pembelajaran dilakukan secara berkala oleh Koordinator Sekolah Dasar dan Pengawas Internal Sekolah. Bentuk pengawasan tersebut seperti pengecekan daftar hadir tutor, daftar hadir siswa, perencanaan pembelajaran, proses pembelajaran, dan proses penilaian. Pengawasan dilakukan setiap dua bulan sekali. Berdasarkan studi dokumentasi tingkat kehadiaran siswa sekolah dasar dalam mengikuti pembelajaran pada tahun ajaran 2017/2018 adalah 91\%. Sedangkan tingkat kehadiran tutor komunitas sekolah dasar homeschooling adalah $95 \%$ dari 15 tutor. Adapun perencanaan pembelajaran 100 persen sudah dibuat oleh tutor, proses pembelajaran sudah menggunakan berbagai metode, dan model pembelajaran, serta proses penilaian sudah menggunakan berbagai cara seperti penugasan, proyek, produk, UTS, UAS, serta USBN. 


\section{KESIMPULAN}

Homeschooling PKBM

Anugrah Bangsa merupakan salah satu pendidikan nonformal yang dijadikan alternatif untuk mengembangkan minat, kemampuan, dan kebutuhan siswa. Pembelajaran program homeschooling tingkat sekolah dasar di PKBM Anugrah Bangsa diawali dengan perencanaan, pelaksanaan, pengawasan, dan penilaian pembelajaran. Perencanaan pembelajaran meliputi pembuatan program tahunan, program semester, silabus, dan rencana pelaksanaan pembelajaran yang disusun setiap awal semester. Pelaksanaan pembelajaran program homeschooling tingkat sekolah dasar di PKBM Anugrah Bangsa dilakukan melalui dua sistem pembelajaran, yaitu 1) sistem komunitas, dan 2) sistem Distance Learning dengan menerapkan berbagai model pembelajaran seperti model Numbered heads Together, Snowball Throwing, Talking Stick, Think Pair Share, dll yang dikombinasikan dengan E-Learning. Penilain pembelajaran yang dilaksanakan antaralain tugas individual, tugas kelompok, tugas proyek, tugas produk, ujian tengah semester, ujian akhir semester, ujian praktik, ujian sekolah bertaraf nasional. Semua siswa dictance learning dan siswa komunitas wajib mengikuti semua jenis penilaian tersebut. Pengawasan pembelajaran dilakukan secara berkala oleh Koordinator Sekolah Dasar dan Pengawas Internal Sekolah. Bentuk pengawasan tersebut seperti pengecekan daftar hadir tutor, daftar hadir siswa, perencanaan pembelajaran, proses pembelajaran, dan proses penilaian.

\section{REFERENSI}

Abdillah, C., Linuwih, S., \& Isnaeni, W. (2017). The Effectiveness of Model Learning Preser-X Assisted LKS Against Science Process Skills and Understanding

Students Concept. Journal of Primary Education, 6(3), 192199.

Ananda, Lisa Rahmi. (2017). Studi Kasus: Kematangan Sosial Pada Siswa Homeschooling. Jurnal Empati, 6(1), 257-263.

Anggara, D. S. (2013). Peningkatan Kualitas pembelajaran IPS melalui model Think Pair Share dengan media CD Pembelajaran pada Siswa Kelas III SD Negeri Kalibanteng Kidul 02 Semarang (Skripsi, Semarang: Universitas Negeri Semarang).

Ariefianto, Lutfi. (2017). Homeschooling : Persepsi, Latar Belakang dan Problematikanya (Studi Kasus pada Peserta Didik di Homeschooling Kabupaten Jember). Jurnal Edukasi, $\mathrm{IV}(2): 21-26$.

Depdiknas. (2003). Undang-undang RI No.20 tahun 2003 tentnag sistem pendidikan nasional.

Fitriana, Ajeng. (2016). Efektivitas

Pelaksanaan Pendidikan

Homeschooling Sebagai

Pendidikan Alternatif Dalam Mengembangkan Potensi Anak Di Homeschoolingkak Seto 
Jakarta Selatan. Jurnal Eksistensi

Pendidikan Luar Sekolah (EPlus), 1(1) : 79-95

Kembara, Maulia D. (2007).

Panduan lengkap

homeschooling. Bandung:

Progressio.

Mulyadi, Seto. (2007)..

Homeschooling Keluarga Kak

Seto. Bandung: Kaifa.

Sugiyono. (2012). Metode Penelitian

Kuantitatif, Kualitataif, dan

$R \& D$. Bandung: Alfabeta

Sumardiono. (2007). Homeschooling lompatan cara belajar. Jakarta:

PT. Elex media kamputindo.

Permendikbud. (2008). Peraturan

Menteri Pendidikan dan

Kebudayaan No. 3 Tahun 2008 tentang standar proses.

Vibriyanthy, Ricca. (2014).

Implementasi Pendidikan

Karakter Di Homeschooling Kak

Seto Yogyakarta. Jurnal

Pendidikan dan Pemberdayaan

Masyarakat, 1(1), 75-85. 